\title{
Correction of cone index for soil water content differences in a coastal plain soil
}

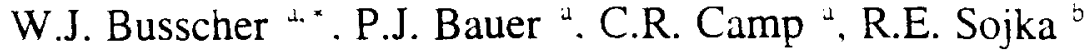 \\ ${ }^{\lrcorner}$Coastai Plains Soil. Water. and Plant Researci Center. USDA-ARS. Florence, SC. US.A \\ "Vorthwest Irrigation and Soils Research Lab. USDA-ARS. Kinberiv. ID. USA
}

Accepted 25 February 1997

\begin{abstract}
Soil penetration resistance (cone index) varies with water content. The field variation of water content could mask treatment differences. The correction of cone index data to a single water content would help prevent this. We used equauons trom TableCurve sortware and trom the literature to correct cone indices for differences in soil water contents. Data were taken trom two field experments where cotton (Gossyptum hirsutum L.) was grown using conventional and conservation tillage without imgation. and beans (Phaseolus iulgaris L.) were grown using conventional tillage with microirrigation. Boundary conditions based on hard. dry and soft. wet soils were imposed on the equations. Equations tit the data with coetficients of determunation ranging trom 0.55 to 0.92 and error mean squares from 1.37 to 6.35 . After correction. cone index dependence on water content was reduced. A single-equation correction did not always tit the data across all treatments. Separate corrections. based on treatment, might be required. When corrections required multiple equations. differences may be real or may be a manifestation of the correction differences. In this case. the correction may not be feasible (uniess some tuture work can coordinate different equations and assure a uniform correction). C 1997 Elsevier Science B.V.
\end{abstract}

Kevwords: Soil strength: Penetrometer: Soil water: Cone index: Coastal plain

\section{Introduction}

Soil penetration resistance as measured by cone index varies with other soil properties such as water content. bulk density, texture. and organic matter (Taylor and Gardner. 1963: Camp and Lund. 1968: Mirreh and Ketcheson. 1972: Spivey et al.. 1986:

\footnotetext{
Corresponding author.
}

()167-1987/97/\$17.00 O 1997 Elsevier Science B.V. All rights reserved. 
Perumpral. 1987: Ley et al.. 1993). Field soil water contents can vary considerably in time and space. This variation and its effect on penetration resistance might mask imposed treatment differences. Correcting penetration resistance tor differences in soil water content could reduce or eliminate the water content etfect on it and improve our measurement and understanding of the impact of management practices on penetration resistance.

Adjustments of flat-tipped. laboratory penetrometer data to a common water content have been successtul (Busscher, 1990), while corrections for cone-tipped. field penetration resistance in the same study were not. Asady et al. (1987) accounted for water content as a continuous covariate of cone index in an analysis of variance (ANOVA). Others have accounted for cone index dependence on water content using this type of analysis (Yasin et al.. 1993).

Several researchers have worked on the relationship between penetration resistance and soil water content. Among them are Ayers and Perumpral (1982). They tound a direct relationship between cone index and bulk density and an inverse relationship between cone index and water content squared for various mixtures of sand and clay. Ohu et al. (1988). on the other hand. found an exponential relationship between cone index and water content for loams and clays. Their equation also included applied compaction pressure. shear strength. and overburden pressure. Ley et al. (1995) found a linear correiation between penetration resistance and water content and a nonsignificant. general relationship between penetration resistance and bulk density. Martino and Shavkewich (1994) found a relationship between penetration resistance and time as water content changed within different tillage systems. Ley and Laryea (1994) used spatial statistics to show a generai relationship between penetration resistance and water content. Even with a lubricated penetrometer (Tollner and Verma. 1987). cone index and water content interactions were tound to be complex.

All empirical and conceptual models that have been proposed to explain penetration resistance include water content as an independent variable. An empirical. mathematical relationship that represents the dependence of cone index on water content can help us understand the relationship between the two. The relationship can help clarify the effect of spatial differences by correcting data to a common water content. Such a relationship could also be usetul for simulations. especially when soil strength and water content are considered as inputs for predicting root growth (Martino and Shavkewich. 1994: Unger and Kaspar. 1994).

Our objective was to tind and use a generalized empirical relationship between cone Index and water content that reciuced or eliminated the dependence of cone indices on water content for massive-structured. sandy Coastal Plain soils.

\section{Materials and methods}

\subsection{Sources of equations}

Cone indices from field expenments were used to test equations that corrected data for differences in water content. We obtained equations developed for this and other 
purposes in the literature and from TableCurve : curve fitting software that uses the least squares method (Jandel Scientific. Corte Madera. CA). TableCurve suggested several hundred equations. We limited the choices based on boundary conditions and on simplicity or the equation. Boundary conditions. based on field experience. were cone indices of zero at or near saturation and high strength (offscale. i.e.. $>10 \mathrm{MPa}$ ) at low $(<0.01 \mathrm{~g} / \mathrm{g})$ water contents. The simpiicity of equations was based on visual judgement of the tit of the equation to the data. Some equations fit the data more closely than those chosen. However. they had a tortuous lit. winding through data points. but not represenung any data trend or physical reality. They were ignored.

The equations chosen were:

$$
\begin{aligned}
& C=a W^{b} . \\
& C=a(1-W)^{b} . \\
& C=a e^{a W} .
\end{aligned}
$$

where $C$ is cone index in $\mathrm{MPa} . W$ is water content on a dry weight basis in $\mathrm{g} / g$. $e$ is the base of natural logarithms. and $a$ and $b$ are empirical parameters that will be calculated and compared throughout the text. Eq. (1) to Eq. (3) can be found in the literature. Eqs. (1) and (2) were proposed by Mielke et al. (1994). They used the equations to solve for water content knowing cone index. We used them in a transposed form to tind cone index from water content. Eq. (3) is similar to an equation used to correct tlat-tipped penetrometer data (Busscher. 1990). We chose to adapt these equations for use on cone-tipped penetrometer data for sandy Coastal Plain soils.

\subsection{Limitations}

The boundary condition of high strength at low water content may be a result of cementation. similar to that seen by Bresson and Moran (1995). This may not be suitable for other soils.

As seen in Section 1, relationships involving cone index and water content. and a variety of other variables have been developed. We assumed that a relationship between cone inciex and water content couid be developed. independent of other variabies.

Other equations. similar to Eqs. (1)-(3). tit the data. For example. $C=a w^{-1}$ was a good tit. However. this was a specific case of Eq. (1) where $b=-1$.

\subsection{Sources of data}

The data used in the experiment were taken from two soil management experiments. The first was a cotton (var. Coker 315) experiment pertormed in 1991 and 1992 at the

\footnotetext{
Mention or trademark. proprietary product. or vendor does not constitute a guarantee or warranty of the product by the US Dept. of Agnc. and does not imply its approval to the exclusion or other products or vendors that may atso be suitable.
} 
Clemson Pee Dee Research and Education Center in Florence. SC. LSA (Bauer and Busscher. 1996). The soil was a Nortolk loamy sand (fine. loamy. siliceous. thermic. Typic Kandiudult). The Norfolk soil has a massive structure and at times may exhibit very weak subangular blocky structure. Cotton was grown on beds that rose $5-10 \mathrm{~cm}$ above the mid-rows. Row widths were $0.96 \mathrm{~m}$.

The experimental field design was randomized complete blocks in a split-split plot arrangement. Main plots were cover crops of vetch (Vicia villosa. Roth) and no cover. Subplots were conventional and conservation tillage. and sub-subplots were depths of measurement. Main plots were $8-\mathrm{m}$ wide by $30-\mathrm{m}$ long. divided eveniy between tillage treatments.

Conventional tillage plots were spring disked and rebedded. Conservation tillage plots were not disked. In conservation tillage plots. beds were reformed by throwing 2.5 $\mathrm{cm}$ or less of soil onto the existing beds with a cultivator betore seeding the cover crop in tall. Both conventional and conservation tiliage included in-row subsoiling to a depth of $25-30 \mathrm{~cm}$ at the time of planting.

Soil strength readings were taken as cone indices on October 1. 1991. and October 26. 1992. shortly atter cotton harvest. Cone indices were taken with a 13 -mm diameter. $30^{\circ}$ solid angle cone tip, hand-operated. recording penetrometer (Carter. 1967). The penetrometer recorded cone indices to $0.55-\mathrm{m}$ depths. Three probings were taken in each plot along the nonwheel-track mid row and digitized into the computer using the method of Busscher et al. (1985). Soil water contents were taken at $10-\mathrm{cm}$-depth intervals and associated with the corresponding cone index readings at that depth.

Cone indices from the surface $25 \mathrm{~cm}$ were ignored because of spring disking in some treatments and spring or fall bedding. Readings were taken in the nonwheel tracks to develop a relationship between cone index and water content without interference from traffic or tillage. Another reason for starting to take readings at $25 \mathrm{~cm}$ is that the root-limiting $E$ horizon in this soil. a hardpan. begins at this depth (Doty et al. 1975).

The equations were also used on data from a green bean (cv. Bush Blue Lake 274) expenment. Plots were established in 1984 at the Coastal Plains Soil. Water. and Plant Research Center near Florence. SC. LSA. approximately $15 \mathrm{~km}$ trom the site of the cotton experiment. We conducted the bean experiment on these plots during the summers of 1988 and 1989 (Camp et al.. 1993). The soil within the plots was also a Nortolk loamy sand with a hardpan below the plow layer.

The field design was randomized complete blocks with four replications. Treatments were irrigated with microirrigation tubing. There were two treatments. placement of the microirrigation tube and frequency of irrigation. with two levels each. Tubes were placed at $0.75-\mathrm{m}$ intervals either on the surtace immediately next to each row or buried at approximately $0.25 \mathrm{~m}$ below the rows. Irrigation was applied at two trequencies: high frequency. where one-third of the application was applied every $4 \mathrm{~h}$ : and low frequency. where the same amount of irrigation water was applied without interruption during the same time period (Camp et al.. 1993).

Because of the buried tube. we could not subsoil annually (the recommended practice for this soil). All plots had been subsoiled in August 1984. In November 1984. microimigation tubes were plowed into the subsurface tube placement treatment using a steel tube attached to a subsoil shank as a guide. Hardpans reconsolidate in these soils to 
root limiting strengths within a vear atter deep tillage by naturai reconsolidation. irattic and disking (Busscher er al.. 1986). All readings were taken in reconsolidated soil.

A surtace irrigation cubing was installed in the plots each year atter pianting. They were removed before trost.

After the end of the bean harvest (July 15.1988 and August 8.1989 ). cone index readings were taken with the hand-held penetrometer. Data were taken and handled using the same method described earlier.

For both cotton and bean data. we analyzed cone index as a function of soil water content and other independent variables using the general linear model (GL.M) ANOVA in SAS (S.AS Institute. 1990). Cone index data were analyzed using a split-split plot randomized complete block design. In the cotton expenment. cover crop was the main treatment with splits on tillage. depth and date of measurement. For the bean experiment. tube placement and irrigation frequency were the main plots with splits on depth and date of measurement. For both data sets. water content was treated as a continuous covanate.

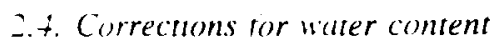

To reduce error mean squares. Eqs. (1)-13) were tit after averaging cone indices and water contents over reps. Corrections were made separately for depth intervals and for treatments. Depths were gathered into two groups based on intervals that did not exhibit ignificant differences in the GLM ANOVA for the original data. These depth intervals were essentially the $E$ and $B t$ horizons of the soils used in the experiments.

Parameters $a$ and $b$ were calculated for each depth interval or treatment by the method of least squares. using TableCurve. Comparisons were made between each treatment pair within experiments. Parameters were compared by calculating an approximate $Z$ siatistic tor each parameter, $a$ and $b$. Eqs. (1)-(3) were compared to one another using a simple $F$ taustic. The $P \leq 19.05$ levef of significance was used. uniess otherwise -pecuiled.

Correctons of cone indices tor ditferences of water content were nased on a first larm or a Taylor senes expansion:

$$
C_{z}=C_{.}+\frac{\mathrm{d} C}{\mathrm{~d} W}\left(W_{0}-W_{.}\right)
$$

where $C$, was the corrected cone index. $C$, was the original cone index. $I F$ was the common water content to which the cone indices were being corrected. $W$, was the onginal water content of $C_{1}$, and $\mathrm{d} C / \mathrm{dW}$ was the first derivative of any one of Eas. (1) -13 ). We chose 11 near the dryer end of the range of water contents. This kept $\left(\mid V_{z}-U\right)>0$ and prevented any calculated $C$. from being less than zero. We chose the Taylor series type of correction. as opposed to a ratio. since it corrected cone indices based on differences of water content. which was the objective of this experiment. We reanalyzed corrected cone indices within GLM in the same manner as uncorrected cone indices listed above. 


\section{Results and discussion}

\subsection{The cotton experiment}

Parameters $a$ and $b$ were calculated and compared tor depths grouped by $0.25-0.35$ $\mathrm{m}$ and $0.40-0.55 \mathrm{~m}$. roughly the $E$ and $\mathrm{Bt}$ horizons. Neither depth interval had significant coefficient of determination $\left(r^{2}<0.2\right)$ for any of Eqs. (1)-(3). Several researchers have shown that the E horizon is growth-limiting based on high soil strength (Doty et al.. 1975: Trouse and Reaves. 1980: Box and Langdale. 1984). We anticipated that horizons. where cone indices differ (Bauer and Busscher. 1996). would have an influence on the correction of cone index for water content. It did not. Depth difference was ignored and data were merged for other parameter calculations.

The difference between years nad similar results. Relationships between cone index and water content for neither year had a significant coefficient of determination $\left(r^{2}<0.22\right.$ for 1991 and $r^{2}<0.47$ for 1992). The difference between vears was also ignored and data were merged for other parameter calculations.

We calculated separate parameters for Eqs. (1)-(3) for each of the four treatments: vetch winter cover-conventionat tillage, vetch winter cover-conservation tillage. tallow winter cover-conventional tillage. and fallow winter cover-conservation tillage. Coetficients of determination ranged from 0.72 to 0.92 (Table 1. Fig. 1).

Tuble 1

Parameters for the cotton experiment calculated by the method of least squares

\begin{tabular}{|c|c|c|c|c|}
\hline \multirow[t]{2}{*}{ Treatment } & \multicolumn{4}{|c|}{ Parameter } \\
\hline & $a$ & $b$ & $\mathrm{ens}^{2}$ & $\overline{r^{-}}$ \\
\hline & $\mathrm{Eq}_{4 .}(1)$ & & & \\
\hline Fal-Conv ${ }^{b}$ & 0.693 & -03.81 & 6.08 & $0.74^{\circ}$ \\
\hline Fial-Cons & 0.634 & $-1) .71$ & 1.37 & 1).920 \\
\hline Vetch-Conv & 0.299 & -1.12 & 5.12 & 1) $89^{\circ}$ \\
\hline \multirow[t]{2}{*}{ Vetch-Cons } & 1.50 & -11.50 & $\therefore 60$ & $11.77^{\circ}$ \\
\hline & Eu (2) & & & \\
\hline Ful-Conv & 10.7 & $\times 12$ & $\therefore: 2$ & $:-2$ \\
\hline Fil-Cons & $\therefore 119$ & 1302 & $1 \div 4$ & $\left.\therefore 9\right|^{\circ}$ \\
\hline Vetch-Conv & 150 & 12.6 & $\therefore 73$ & $: 157^{\circ}$ \\
\hline \multirow[t]{2}{*}{ Vetch-Cons } & 8.58 & 5.64 & $\therefore 61$ & $1.77^{\circ}$ \\
\hline & Eq. (3) & & & \\
\hline Fal-Conv & 11.1 & -8.96 & 6.30 & $0.72^{\circ}$ \\
\hline Fal-Cons & 8.31 & -9.74 & 1.48 & i) $91^{\circ}$ \\
\hline Vetch-Conv & 15.7 & -13.8 & 5.66 & $11.87^{\circ}$ \\
\hline Vetch-Cons & 8.76 & -6.16 & $\therefore 60$ & i) $77^{\circ}$ \\
\hline
\end{tabular}

'Error mean square.

"Fal-Conv: tallow conventional: Fal-Cons: tallow conservation: Vetch-Conv: vetch conventional: Vetch-Cons vetch conservation. Number of data $(n)$ after averaging over + reps: $n=1+$ for Fild-Conv. Fal-Cons Vetch-Conv. and Vetch-Cons.

Signiticant at the $P \leq 0.01$ levels or less. 


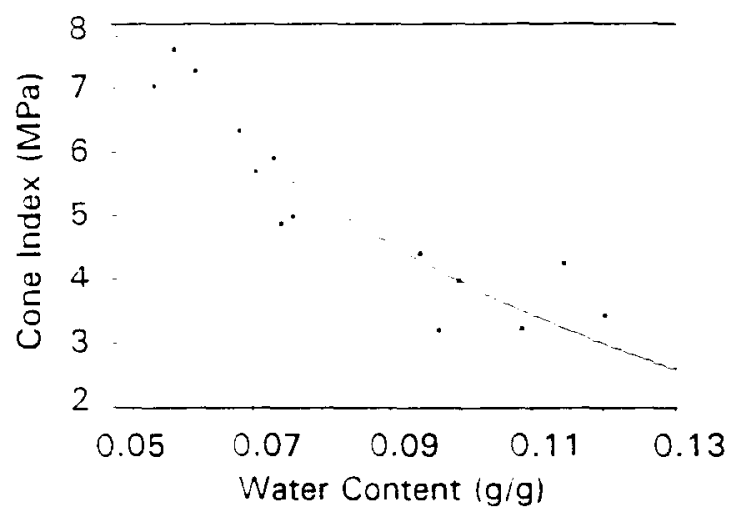

Fig. 1. Cune index vs. water content tor vetch winter cover conservation tillage with Eq. $(2)(C=a i-(1)$, . Data were used to determine parameters $a$ and $b$ of Table 1 with the method of least squares.

We compared the parameters for the four treaments to one another. First. We compared vetch conservation tulage to fallow conservation tillage. Parameters $a$ and $b$ were significantly different at the $P \leq 0.01$ level. Second. we compared vetch conventional tillage to fallow conventional tillage. Here. $b$ was significantly different at $P \leq 0.05$ for Eqs. (2) and (3). Parameter differences for cover crop treatments were unexpected since we ignored the upper $0.25 \mathrm{~m}$ of the profile. However. we observed less water ponded on cover crop plots during heavy rains. A deep cover crop effect could be the result of improved infiltration and reconsolidation within the vetch plots. Third, we compared vetch conservation tiliage to vetch conventional tillage. Parameters $a$ and $b$ were significantly different at the $P \leq 0.01$ level of significance. Finally, we compared fallow conservation tillage to tallow conventional tillage where neither parameter $a$ nor $b$ was different.

We also calculated a set of parameters for all four treatments taken together. These parameters did not tit any of Eas. (1)-13) $\left(r^{-} \sim 0.39\right)$. as well as parameters for the individual treatments (Fig. 2 ).

Cune indices were cortected tor water content with Eq. (t). Here. we used both a ingle-equation correction tone equation for all treatments taken together) and a muitiple-equation correction (tour equations with the separate parameters tor each treatment. Table 1). Uncorrected and corrected cone indices were analyzed in GLM. The ANOVA for corrected cone indices was analyzed two ways. with and without the original water contents in the design. We used the design with water content to see it the cone index dependence on water content was reduced or eliminated. The design without the water content was the proper design after elimination or the water content as an independent variable. Both designs gave the same results, unless otherwise specified.

Before correction. cone index varied with water content in GLM with an $F$ value of 19. We reanalyzed the data atter a single-equation and a multiple-equation correction with water content in the AVOVA design. The $F$ value was reduced for both cases (Table 2). Corrected cone indices generally reduced the model error mean squares (ems). which would increase the $F$ ialue. However. water content ems were also reduced (Table 2). As a result. the $F$ value and its effect on cone index were reduced. In one 


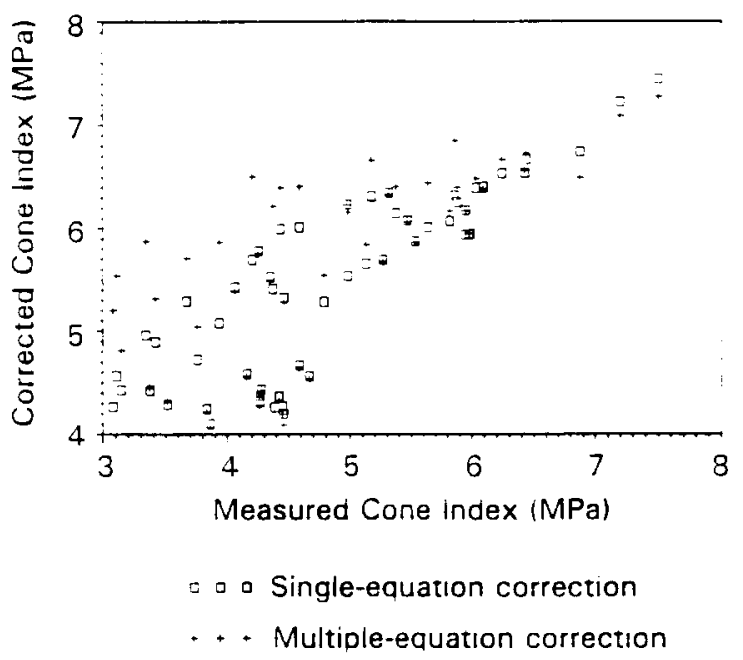

Fig. 2. Corrected vs. measured cone indices tor all cotton data using Eq. (2) and paramerers trom Tabie 1.

instance. Eq. (1) with the multiple-equation correction. model ems increased. Here. the water content ems was lowest and $F$ values were not significant. For the other equations. ems values were about the same. Both had lower $F$ values than the uncorrected case showing reduced significance. Water content ems were lower tor multiple-equation corrections than tor single-equation corrections. presumably because multiple-equation corrections tit the data better.

Within the ANOVA of the uncorrected data. cone indices for winter cover and tillage treatments were not different. After correction. cone indices for winter cover were not different: cone indices for tillage treatments were different for the multiple-equation corrections of Eys. (2) and (3) at $P \leq 0.01$ and 0.07 . respectively (Table 3. both were $P \leq 0.04$ for the design without the water content). Water contents of conventional (iilage $(0.087 \mathrm{~g} / \mathrm{g}$ with 0.029 standard deviation) and conservation tillage $10.074 \mathrm{~g} g$ with 0.023 standard deviation) were corrected to 1$) .06 \mathrm{~g} / \mathrm{g}$. The greater correction tor the conventional tillage led to the increased difterence between the two and the igniricant difference. Cone indices for conventional tillage were higher than those for

Table 2

Cincorrected and corrected error mean squares (ems) and $F$ :alues for the cotton expenment

\begin{tabular}{|c|c|c|c|c|c|c|}
\hline \multirow[t]{2}{*}{ Correction } & \multicolumn{3}{|c|}{ Singie-equation correction } & \multicolumn{3}{|c|}{ Multiple-equation correction } \\
\hline & $F$-value & Model ems & Water ems & F-value & Model ems & Water ems \\
\hline none & 19.2 & 0.0065 & 0.126 & 19.2 & 1).0065 & $1) .126$ \\
\hline Eq. (1) & 2.33 & 1). 0082 & 0.019 & 11.12 & 0.0110 & 0.001 \\
\hline Eo. (2) & 5.12 & 1). 0055 & 0.028 & 2.68 & 1).0056 & 1).015 \\
\hline Eq. (3) & 5.17 & 0.0055 & 0.028 & 2.65 & 1).0056 & 0.015 \\
\hline
\end{tabular}


Table 3

Wean cone indices: uncorrected and corrected tor differences in water content for the cotton expenment

\begin{tabular}{|c|c|c|c|c|c|c|c|c|}
\hline \multirow[t]{3}{*}{ Equation } & \multicolumn{4}{|c|}{ Singie-equilion correction } & \multicolumn{4}{|c|}{ Multuple-equatuon correction } \\
\hline & \multicolumn{2}{|c|}{ Vetch cover } & \multicolumn{2}{|l|}{ Fallow } & \multicolumn{2}{|c|}{$V$ etch cover } & \multicolumn{2}{|l|}{ Fallow } \\
\hline & $\begin{array}{l}\text { Cunser- } \\
\text { vation }\end{array}$ & $\begin{array}{l}\text { Cunven- } \\
\text { ilonal }\end{array}$ & $\begin{array}{l}\text { Conser- } \\
\text { vacuon }\end{array}$ & $\begin{array}{l}\text { Cunven- } \\
\text { tional }\end{array}$ & $\begin{array}{l}\text { Conser- } \\
\text { : atuon }\end{array}$ & $\begin{array}{l}\text { Cunven- } \\
\text { lional }\end{array}$ & $\begin{array}{l}\text { Cunser- } \\
\text { batıon }\end{array}$ & $\begin{array}{l}\text { Cunven } \\
\text { ionai }\end{array}$ \\
\hline $\begin{array}{l}\text { uncor- } \\
\text { rected }\end{array}$ & $\therefore 21$ & -87 & +16 & +82 & $\therefore .21$ & -.87 & +.16 & $\div 82$ \\
\hline Eq. (1) & $5.74^{4}$ & $\therefore 50$ & $\therefore 90$ & 5.53 & 5.72 & 5.75 & 3.84 & $=79$ \\
\hline Eq. (2) & $\therefore 89$ & 5.71 & +36 & 5.77 & 5.87 & 6.23 & +.33 & 0.03 \\
\hline Eq. (3) & $\therefore 88$ & $\therefore 70$ & +34 & 5.74 & 5.36 & 5.20 & \pm .31 & hol \\
\hline
\end{tabular}

${ }^{2}$ Higher corrected cone indices restect the lower water content used as a standard.

Values are expressed in .MPa.

conservation tuilage betore (4.95 vs. $+.76 \mathrm{MPa})$ and atter $(6.22 \mathrm{ks} .5 .1+\mathrm{MPa}$ tor Eu. (2)) multiple-equation correction.

If the single-equation correction was suitable. we could have stated that there were differences in the tillage treatment after correction that did not exist betore. or that the water content differences betore correction had masked treatment differences. However. since only the multiple-equation correction was meaninglul, differences after correction may reflect real differences or may be a manifestation of the different corrections.

If we assume that the treatment differences atter correction are real. higher cone indices tor conventional tillage are reasonable. These plots were disked: conservation tillage plots were not.

\subsection{The bean experiment}

When parameters were anaivzed for depth or year. bean data had results similar to cotton. Depth intervals did not have a significant relationship $\left(r^{-}<0.27\right)$. Analysts by year had acceotable regressions $\left(r^{-}=0.61-0.6+\right.$ and ems $\left.=0.06-6.22\right)$ but no signiticant differences. We ignored depth and year and merged data tor other calculations.

We calculated separate parameters for Eqs. (1)-13) for both high and low trequency irrigation and for both buried and suriace microirrigation tube placement (Table 4). For irrigation trequency. no differences were found between parameters. For microirngation tube placement, parameter $b$ was different at $P \leq 0.05$ for all equations. The singleequation tit of all treatments was reasonable $\left(r^{2} \sim 0.64\right.$ and ems $\left.\sim 0.0\right)$.

Cone indices were corrected for water content (Eq. (4)) using parameters from different tube placement treatments. multiple-equation correction. and using the singleequation rit (Fig. 3). Corrected cone indices were reanalyzed in GLM in the same manner described eurlier. Designs with and without water content gave the same results. unless otherwise stated.

Before correction. cone index varied with water content with an $F$ value of 49 . Single- and multiple-equation corrections reduced $F$ values. especially for Eqs. (2) and (3) (Table 5). For the corrected cone indices. the model ems were reduced: the water 
Tuble 4

Parameters tor the bean experment calculated bv the method of least squares

\begin{tabular}{|c|c|c|c|c|}
\hline \multirow[b]{2}{*}{ Treatment } & \multicolumn{4}{|c|}{ Parameter } \\
\hline & $\therefore$ & $b$ & $\therefore \mathrm{ms}^{-}$ & $r$ \\
\hline & \multicolumn{4}{|l|}{ Eq. (I) } \\
\hline Surtace & 11.088 & -1.85 & 5.63 & $0.70^{\circ}$ \\
\hline Buried & 1). 272 & -1.34 & 6.12 & $0.58^{\circ}$ \\
\hline Hi-frequency & 1). 210 & -1.41 & h. 20 & $0.55^{\circ}$ \\
\hline \multirow[t]{2}{*}{ Lo-trequency } & 0.106 & -1.74 & 5.62 & $0.72^{\circ}$ \\
\hline & \multicolumn{4}{|l|}{ Eq. (2) } \\
\hline Surtace- & 17.5 & 10.8 & 5.65 & $0.70^{\mathrm{b}}$ \\
\hline Buried & 11.4 & 7.99 & 6.07 & $0.59^{\circ}$ \\
\hline Hi-frequency & 12.1 & 8.31 & 0.15 & $0.56^{\mathrm{D}}$ \\
\hline \multirow[t]{2}{*}{ Lo-irequency } & 15.9 & 10.4 & 5.60 & $0.72^{\circ}$ \\
\hline & \multicolumn{4}{|l|}{ Eu. (3) } \\
\hline Surtace & 20.2 & -12.7 & 5.64 & 1). $.70^{\mathrm{D}}$ \\
\hline Buned & $: 26$ & -4.36 & 6.07 & 1). $59^{\circ}$ \\
\hline Hi-freauency & $1: 5$ & -4.77 & 6. 15 & $0.56^{\circ}$ \\
\hline$\left.L_{-1}\right\}$-irequency & $\vdots \times 2$ & -12.2 & $\therefore 60$ & $11.72^{n}$ \\
\hline
\end{tabular}

Error mean square.

"Signiticant at the $P \leq 11.01$ levels or less.

Vumber of data $(n)$ atter averagung over + reps: $n=5+$ for Surtace. Buried. Hi-. and Lo-trequency.

content ems were reduced even more. Reductions of $F$ and ems were about the same for either single- or multiple-equation corrections (Table 5. Fig. 3).

In the ANOVA of uncorrected data. cone indices were not significantly different for tube placement or trequency of irrigation treatments. After either single- or multiple-

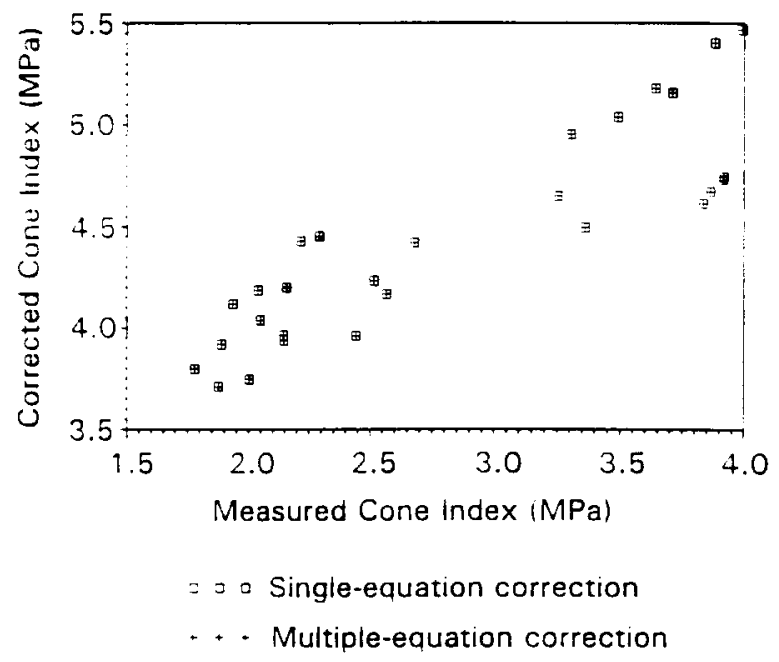

Fig. 3. Corrected vs. measured cone indices tor the green bean data usıng Eq. (2) and parameters trom Table 3. 
Tuble 5

Lncorrected and corrected error mean suuares (ems) and $F$ values tor the bean expenment

\begin{tabular}{|c|c|c|c|c|c|c|}
\hline \multirow[t]{2}{*}{ Correction } & \multicolumn{3}{|c|}{ 1) ne-equation correction } & \multicolumn{3}{|c|}{ Two-equation correction } \\
\hline & $F$-value & Model ems & Water ems & $F$-value & Model ems & ivater ems \\
\hline none & +9.0 & 0.09205 & 1.01 & +4.0 & 10.0205 & $1.1) 1$ \\
\hline Eч. (1) & $2+.9$ & 0.0088 & 1).22 & 25.4 & 0.0090 & 0.23 \\
\hline Eч. (2) & 6.24 & 0.0086 & 0.054 & 0.62 & 0.0088 & 0.058 \\
\hline Eu. (3) & 8.50 & 0.0086 & 1).073 & 9.04 & 0.0088 & 1).080 \\
\hline
\end{tabular}

equation corrections. cone indices were different $(P \leq 0.01)$ for tube placements (Table 6). For uncorrected values. cone indices of the buried treatment were greater than the surface treatment $(2.90 \mathrm{vs}, 2.72 \mathrm{MPa})$. For single- and multiple-equation corrections. cone indices for the surtace treatment were greater than for the buried treatment 14.62 vs. $+.3+\mathrm{MPa}$ using Eq. (3)).

The water contents of buried placement $(0.15 g / g$ with 0.031 standard deviation) and surtace placement $(0.16 \mathrm{~g} / \mathrm{g}$ with 0.027 standard deviation) were corrected to $11.10 \mathrm{~g} / \mathrm{g}$. The greater correction for the surtace treament led to its higher cone indices after correction and its signiticant difference.

Since the single-equation correction was suitable. cone index differences between the buried and surface treatments were masked by differences in water content betore correction. The single-equation correction was about the same as the multuple-equation correction. Differences tor tube placement could be a result of different reconsolidation caused by irrigation water entering the soil at the surface or in the subsurtace.

\subsection{Differences among the equations}

In an attempt to improve the relationship between cone index and water content. we forced the cone index of the empirical relationship to go through zero at $40 \%$ water content. Forty percent is the approximate value of saturated water content. This was accomplished by adding a term $(1) .+-W)$ to each of Eqs. (1)-(3). It did not improve the relationship. In fact. there were tew differences between Eqs. (1)-13) and these

Tuble 0

Vean cone indices: uncorrected and corrected for ditferences in water content tor the green bean experiment

\begin{tabular}{|c|c|c|c|c|c|c|c|c|}
\hline \multirow[t]{3}{*}{ Equation } & \multicolumn{4}{|c|}{ Single-equation correction } & \multicolumn{4}{|c|}{ Wultiple-equation correction } \\
\hline & \multicolumn{2}{|c|}{ Tube placement } & \multicolumn{2}{|c|}{$\begin{array}{l}\text { Irrigation } \\
\text { irequency }\end{array}$} & \multicolumn{2}{|c|}{ Tube placement } & \multicolumn{2}{|c|}{$\begin{array}{l}\text { Imgation } \\
\text { irequency }\end{array}$} \\
\hline & Buned & Surtace & $\mathrm{Hi}$ & Lo & Buried & Surtace & $\mathrm{Hi}$ & Lo \\
\hline uncorrected & 2.80 & 2.61 & 2.76 & 2.65 & 2.80 & 2.61 & 2.76 & 2.65 \\
\hline Eq. (1) & $+.28^{4}$ & +.15 & 4.27 & +16 & +12 & +36 & 4,30 & $\therefore 18$ \\
\hline E4. (2) &.++3 & +35 & 4.46 & 1.32 & -27 & +.56 & +49 & $\div 34$ \\
\hline Eu. (3) & +41 & +32 & 4.4 & +30 & +25 & +52 & $4+5$ & $\div 31$ \\
\hline
\end{tabular}

'Higher corrected cone indices reflect the lower water content used as a standard.

Values are expressed in MPa. 
equations. Furthermore. we compared all six equations to one another with simple $F$ tests that used the ems of the various tits (data not shown: most $F=1$ ). No single equation was ever statistically better than another.

\section{Conclusions}

Significant differences between parameters were caiculated for some different treatments. At times. different treatments require separate parameters to correct cone indices for water contents. Ley et al. (1993) reported similar results. They had different slopes for tensile strength vs. water content of different management treatments. The need for different equations for different treatments may account for the difficulty that researchers. such as Busscher (1990). had in developing this relationship in the past.

When corrections can be made with a single equation. corrected cone indices can be reinterpreted. Changes in cone index treatment significance as a result of the correction can be interpreted as having been masked by the differences in water content. When corrections require multiple equations. differences may be real or may be a manitestation of the correction differences. Multiple-equation corrections cannot guarantee that the differences are a result of the correction tunless some way to coordinate the equations and to assure a uniform correction can be found). In this case. water content can still be used as an independent variable in the GLM (Asady et al.. 1987). But this assumes a linear relationship.

We found a few differences among the equations that were used to fit the data. Eqs. (2) and (3) showed differences between parameters for separate treatments when Eq. (1) did not. Further. corrected cone indices using Eqs. (2) and (3) showed differences among treatments in the ANOVAs of corrected cone indices when Eq. (1) did not.

Correction of cone index for water content led to a decreased significance of cone index dependence on water content within GLM anaivses. This was true whether we used a one-equation correction of cone index for water content. or a more-than-oneequation correction based on treatments.

Correction of cone index for water content led to increased signiricance of treatment differences. If a one-equation correction was used. this difference had been masked by differences in water content betore correction. If a multiple-correction equation was used. the difference may be real or a result of different corrections.

\section{References}

Asady. G.H.. Hook. J.E. Threadgili. E.D.. 1987. Tillage induced modifications or cone index and buik densıty in a Coastal Plain soil. Agronomy Abstracts. p. 235.

Ayers. P.D.. Perumprai. J.V. 1982. Moisture and density etfect on cone index. Trans. ASAE 25 (5). $1169-1172$.

Bauer. P.J.. Busscher. W.J.. 1996. Winter cover and tillage intluences on Cuastal Plain cotton production. J. Prod. Agnc. 9 (1). 750-754

Box. J.E.. Lingdale. G.W.. 1984. The effects of in-row subsoil tillage on com yields in the southeastern Coastal Plains of the Linited States. Soil Till. Res. $4.67-78$. 
Bresson. L..M.. Moran. C.J., 1995. Structural change Induced by wetung and dring in seedbeds of a hardsetting soil with contrastung aggregate size distribution. Eur. J. Soil Sci. th 12). 205-214.

Busscher. W.J. 1990. Adiustment of tiat-tipped penetrometer resistance data to a common witer content. Trans. ASAE 33 12). 519-524.

Busscner. W.J.. Solka. R.E.. Doty. C.W., 1986. Residual ertects or tillage on Cuastal Plain soti strength. Soil Sci. $141,1+4-148$

Busscher. W.J.. Sojka. R.E.. Sadler. E.J.. Doty. C.W.. 1985. Simplitied data analysıs tor an inexpensıve. manual analogue penetrometer. Conput. Elect. Agric. 1. 197-204.

Camp. C.R.. Garrett. J.T. Sadler. E.J.. Busscher. W.J.. 1993. Microimgation management for double-cropped vegetables in a humid area. Trans. ASAE 36 (6). 1639-i644.

Camp. C.R.. Lund. Z.F.. 1968. Effect of mechanical impedance on cotton root growth. Trans. ASAE 11 (2). $188-190$

Carter. L.M.. 1967. Portable penetrometer measures soil strength protiles. Agric. Eng. $48.348-349$

Doty. C.W. Campbeil. R.B.. Reicosky. D.C. 1975. Crop response to chiseling and imgation in soils with a compact A2 horizon. Trans. ASAE 18 (4). 668-672.

Ley. G.J.. Larvea. K.B.. 1994. Spatial vanability in penetration resistance of a hardsetting tropical altisol. Soil Till. Res. $29(4) .367-381$.

Ley. G.J. Mullins. C.E.. Lal. R.. 1993. Effects of soli propernes on the strength of weak structured tropical -ants. Soil Till. Res. $23.1-13$.

Ley. G.J., Mullins. C.E.. Lal. R.. 1995. The potentual restnction to root growin in structurativ weak tropical soils. Son Till. Res. 33 (2). 133-142.

Martino. D.L.. Shavkewich. C.F.. 1994. Root penetration protiles of wheat and barley as artected by sol penetration ressistance in tield conditions. Cin. J. Soil Sci. $7+12) .193-200$

Mielke. L.N.. Powers. W.L.. Budri. S.. Jones. A.J.. 1994. Estimating soll water content trom soll strength. Soil Till. Res. 31. 199-209.

Mirreh. H.F.. Ketcheson. J.W.. 1972. Intluence of bulk density and matric pressure to soll resistance to penetration. Can. J. Soil Sci. 52. $477-483$.

Ohu. J.O.. Raghavan. G.S.V.. McKyes, E., 1988. Cone index prediction of compacted soils. Trans. ASAE 31 12). $306-310$.

Penumprai. J.V.. 1987. Cone penetrometer application: A review. Trans. ASAE 30 (4). 939-414

SAS Institute. 1990. SAS Linguage: Reference. Version 6. SAS Institute. SAS Circle. Box 80()). Cary. NC $27512-8000$.

Spivey. L.D. Jr.. Busscher. W.J.. Campbell. R.B.. 1986. The effect of texture on strength in southeastem Coastal Plain solis. Soil Till. Res. 6. 351-363.

Tuvior. H.M., Gurdner. H.R.. 1963. Penetration of cotton seedling taproots as intluenced by hulk density. molsture content. and strength of the soil. Soil Sci. 96. 153-156.

Tollner, E.W Verma. B.P. 1987. Lubricated and noniubncated cone penetrometer pertormance companson in $y x$ solis. Trans. ASAE 3016$) .1611-1018$.

Trouse. A.C. Reaves. L.A. 1980. Reducing energy inputs into no-liliage systems. In: Gallaher. T.... (Ed.). Vo-tillage Systems. 19 June 1980. Univ. of Florida. Guinesville. FL. p. 188-195.

Unger. P.W.. Kaspar. T.C. 1994. Soil compacuon and root growth - a review. Agron. J. b6 (5). $759-766$.

Yusin. M.. Grisso. R.D.. Bashrord. L.L.. Jones. A.J. Mielke. L.N.. 1993. Normalizing cone resistance values by covarance analysis. Trans. ASAE $36(5), 1267-1270$. 